\title{
Towards a beneficial World Heritage: community involvement in the Blaenavon Industrial Landscape
}

\section{Dominic Walker, Department of Archaeology, University of Cambridge}

Community involvement has become a ubiquitous element of heritage management in recent years. These emergent collaborative practices should ideally entail professionals or academics working in a mutually beneficial partnership with other communities, possibly other professional communities, but particularly local community groups who may be profoundly affected by the decisions made about their cultural heritage. However, the ways in which principles such as 'collaboration' have been interpreted in practice has varied immensely and may be more akin to 'consultation' or more superficial forms of inclusion (Colwell-Chanthaphonh and Ferguson, 2008a). This means that the various benefits that heritage professionals envisage when initiating projects with communities may not be forthcoming. In this article, I will discuss the ways in which the local community has been involved in the management of the Blaenavon Industrial World Heritage Site in Wales. Through this case study, I assert that heritage professionals should more critically engage with the concerns, needs and values of local communities in order to more effectively realize economic and social aims.

\section{The problems with multi-functional heritage}

Heritage is utilized in both social and economic regeneration processes around the world. UNESCO World Heritage listing in particular may be regarded as a way to achieve localized aims, often related to stimulating economic gain through tourism. However, the use of heritage in economic strategies can challenge the social benefits. For instance, industrial heritage sites often present sanitized or romanticized interpretations, rather than inciting debates about inequalities or contemporary concerns, such as whether we now have truly democratic workplaces, which might lead to social change (Uzzell, 1998; Summerby-Murray, 2002). In fact, the social benefits of involving local communities in heritage management have been highlighted in United Kingdom heritage policy discourse since the mid-1990s, 
particularly in relation to the political notion of social exclusion/inclusion. Despite political movements, and other theoretical shifts that have encouraged collaborative practices (e.g. Swidler et al., 1997), heritage professionals may be considered as remaining in a strong position of power from which they can make judgements about the relative worth of different views about heritage. Laurajane Smith and Emma Waterton (2009) posit that heritage policy continues to be rooted in scientific positivism, which authorizes the 'expert' views of professionals and in turn allows them to consider alternative, local viewpoints as irrelevant or merely a footnote in a mainstream version of heritage that values the monumental and aesthetically-pleasing features of heritage.

I contend that this position of authority has been somewhat diminished in recent years - at least in the United Kingdom. English Heritage, for instance, has begun to accept the views of non-heritage-professionals as of equal worth to that of heritage professionals (see English Heritage 2010: 13-15). Nevertheless, the problems with dealing with different types of value may be exacerbated in the case of UNESCO World Heritage Sites. Firstly, 'universal value' is added as a contesting value at World Heritage Sites, and secondly, they may also act as a focus for a government's efforts to encourage economic or social regeneration (at a local, regional or national level). UNESCO has attempted to emphasize people and cultural values in conventions and guidelines in recent years (UNESCO, 1994a, 2003), but it is still possible to identify numerous sites where the needs and values of local people are excluded in favour of preserving the aesthetic or historic for touristic consumption (e.g. de Merode et al., 2004). Moreover, there is often no direct access for local communities in the decision-making process in World Heritage management. This being the case, we must ask how the conservation of universal values at World Heritage sites may be made commensurable with addressing local viewpoints. Is it possible for social benefits to emerge from World Heritage management, or merely the economic benefits related to tourism? Moreover, what role should the heritage professional play in all of this? 


\section{Blaenavon: revolution to regeneration}

The 'outstanding universal value' of the Blaenavon Industrial Landscape lies in it comprising well-preserved evidence of the social, economic and technological processes of industrialization, particularly in relation to nineteenth century developments (Blaenavon Partnership, 1999). The 32.9 square-kilometres World Heritage landscape encapsulates numerous individual sites, wherein the major visitor attraction is the Big Pit - a coalmine sunk in 1880 but now serving as a national coalmining museum (Figure 1). Other notable elements are: the town itself, the Workman's Hall built in 1894 (and still in regular community use), the Ironworks, and the upland natural landscape (Figure 2).

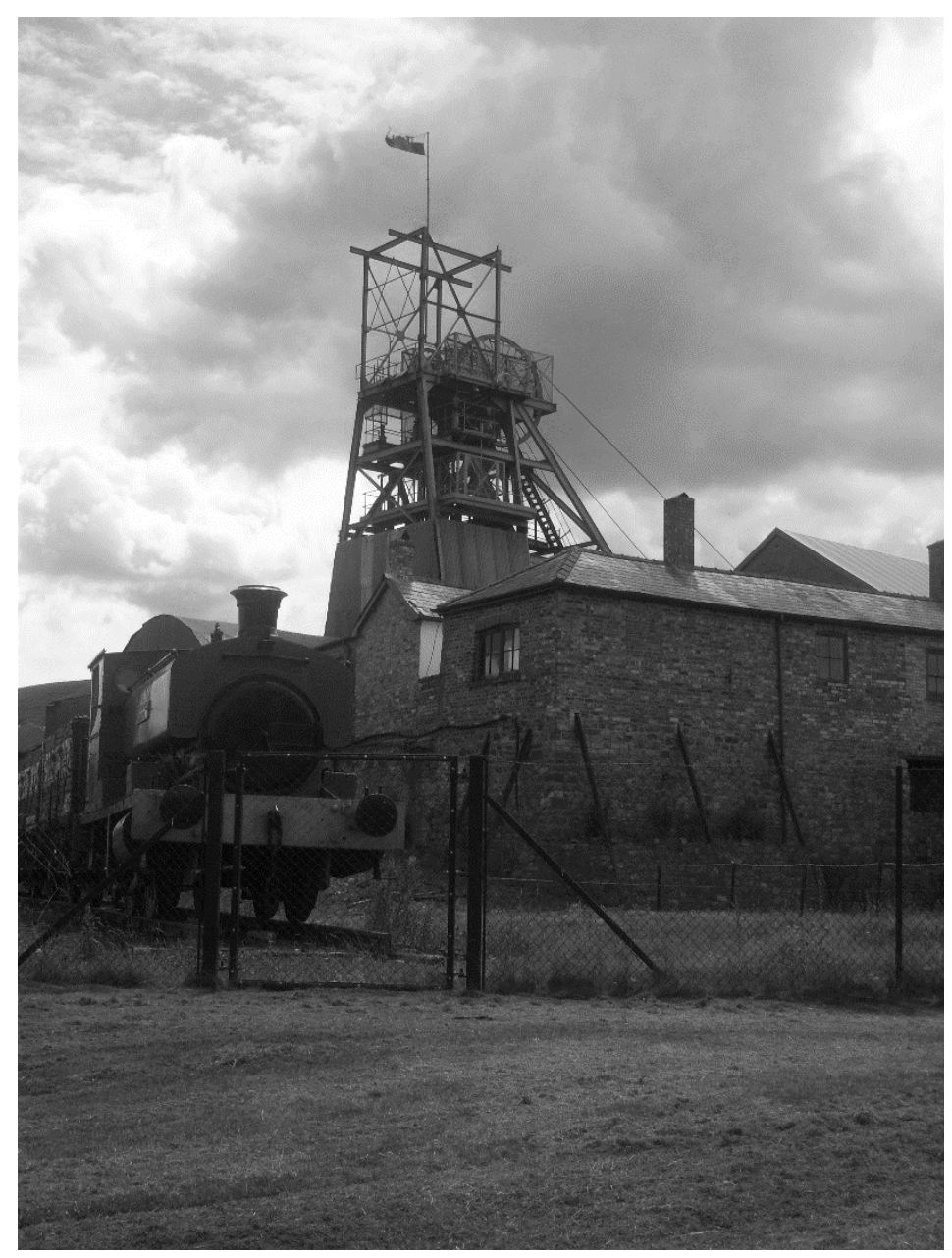

Figure 1. Big Pit: National Coal Museum (Wales, UK). (c) Dominic Walker, 2010. 


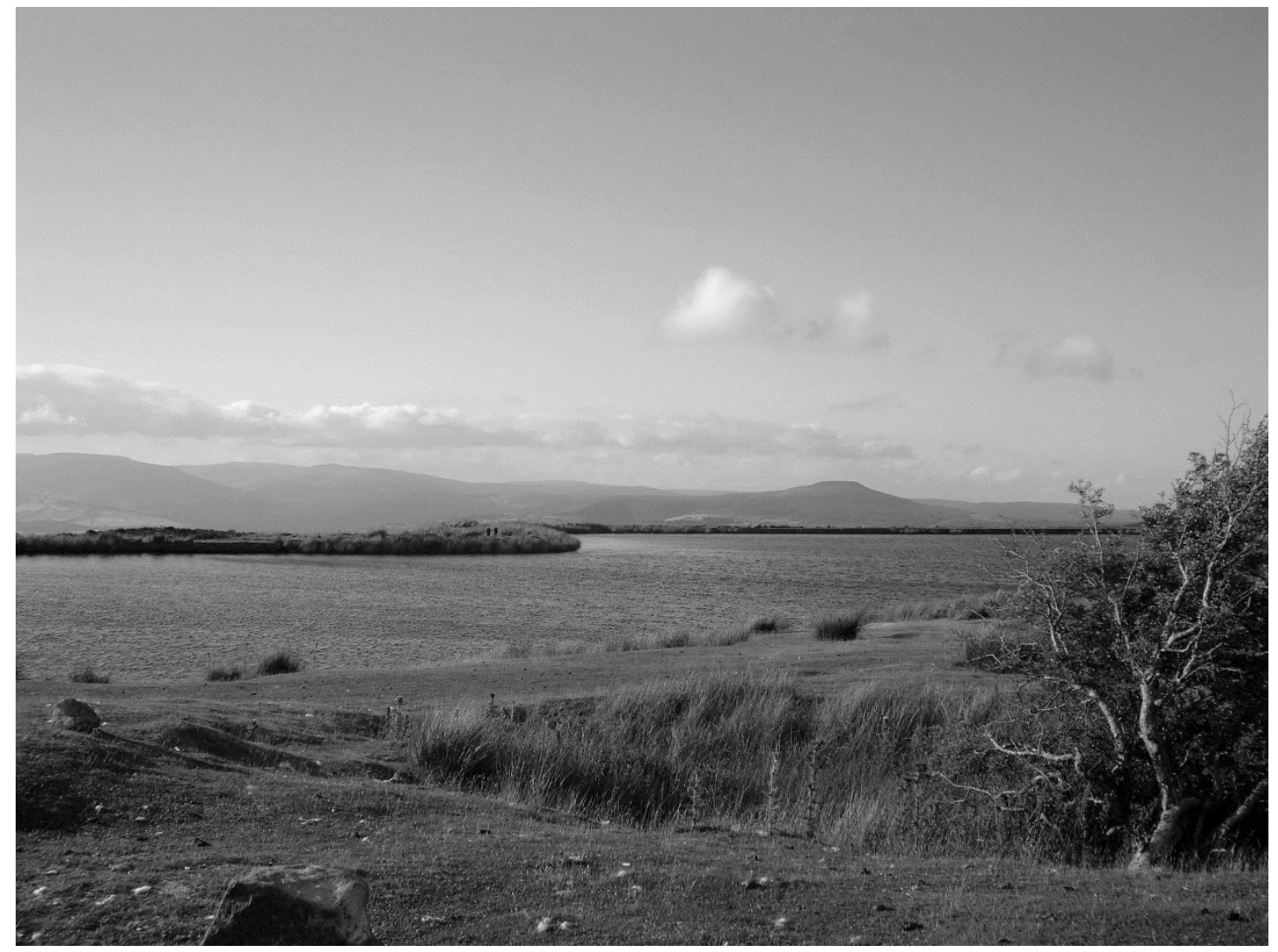

Figure 2. Upland natural landscape inscribed within the Blaenavon world heritage site. (C) Dominic Walker, 2010.

Economic and social decline resulted from the deindustrialization process that began in the early twentieth century. Steelmaking ceased in the 1930s and coalmining declined and eventually ended in 1980. The local government, Torfaen County Borough Council (TCBC), considered the use of heritage in economic and tourism strategies from the 1970 s as a solution to some of the main problems resulting from deindustrialization, namely population decline, high unemployment rates and a perceived lack of social wellbeing (Blaenavon Partnership, 1999). Big Pit opened as a successful mining museum in 1983 but as a result of its situation on the town outskirts museum visitors rarely ventured into the town itself. As a result, the museum did not save the town's economy and unemployment persisted alongside associated hardships.

From 1997, TCBC realized that heritage tourism could not secure the salvation of the town's economy, but it could offer a "catalyst for regeneration" 
(TCBC, 1997), which would be helped by inducing a sense of social wellbeing from within the community. In order to aid the regeneration process and the bid for World Heritage status, TCBC established the Blaenavon Partnership in 1999, which was lead by council-employed heritage professionals and included politicians and representatives of the individual heritage sites within the nominated World Heritage landscape. The Partnership helped to secure Blaenavon's inscription onto the World Heritage list in 2000, but its inclusion may be considered a partial result of national political agendas as well as attempts to expand the types of sites accepted to be worthy of the status of national heritage and World Heritage (e.g. UNESCO, 1994b). Since the inscription, the economic benefits have been obvious: new jobs in tourism, rising property values, and a population increase for the first time in 90 years (now 7000 people; Blaenavon Partnership, 2010).

Despite being inscribed as a Cultural Landscape, meaning the management of local cultural values should be balanced with universal values, decisions about the site are almost the sole reserve of a few professional and political stakeholders. Significantly, there is no formal method by which other members of the public can become involved in the planning or implementation of individual projects or the overall objectives of the Partnership. This remains "by invitation" only (Blaenavon Partnership, 2010: 110). Despite the good intentions of individual heritage professionals, the current exclusive management structure means local people cannot be true collaborators in democratic decision-making.

The management of the World Heritage Site is made particularly complex due to the number of constituent sites included in the inscribed landscape and the variety of stakeholders interested in these sites. Big Pit is particularly interesting in this respect because of its role in representing the Welsh coalmining experience while existing in a landscape declared to be of universal value, in addition to the many personal and local values attached to it. Here, however, I will focus on the involvement of the local community in town centre projects because they more clearly illustrate the tensions that arise between heritage professionals and local residents in practice. 


\section{Community involvement in practice}

The physical regeneration of the built fabric of Blaenavon town centre began in earnest from 1999. Several historical shop fronts were reconstructed in order to encourage inward financial investment as well as helping to instil a sense of pride in the town. In 2003 there was an attempt to transform Blaenavon into a 'booktown'-a town of collectors' bookshops. This was hyped in the media but the project ultimately failed: nine bookshops opened in June 2003 but most had closed by June 2004. This was regularly mentioned in my interviews, with both locals and professionals, indicating the significance of the failure. Although the project was financed by an external organization, the Blaenavon Partnership publically supported the project and therefore the failure of the project was also associated with them.

A degree of the ill feeling felt by local residents towards the heritage professionals seems to be related to the lack of involvement in decision-making about their town, especially since economic regeneration has been a prioritized yet only partially achieved aim. Indeed, still only a small fraction of the c.180,000 annual visitors to Big Pit travel into the town itself and spend their money in shops. Thus, despite the good intentions and hopeful predictions, mistrust has developed between residents and heritage managers.

A simple lack of effective dialogue may account for this distrust. Today, Broad Street, the main thoroughfare in Blaenavon, is largely split between locallyorientated businesses and tourist shops, which occupy the renovated historic buildings. In my interviews it became evident that the owners of the 'local shops' generally felt that tourists do not use their shops, but "just go up to the boutique shops". Conversely, several owners of 'tourist shops' moved into Blaenavon from other regions of Wales, and felt that they suffer from a degree of hostility from the owners of locally-established businesses. This hostility was apparently due to a feeling amongst locals that TCBC helped the new residents set up shop.

Strong feelings of ownership are felt towards parts of the built heritage. For example, many locals feel that they have a firm stake in the ownership of The 
Workman's Hall (now owned by the council) since preceding generations paid to fund its construction and maintenance (Figure 3). In an interview, one individual used the phrase "by the people for the people". Feelings like this indicate the existence of a dichotomy between 'insider' and 'outsider' status. Indeed, many locals consider the professionals to be outsiders, even if they come from a few miles away, simply because they had not truly engaged with local aspirations, values, and "local knowledge".

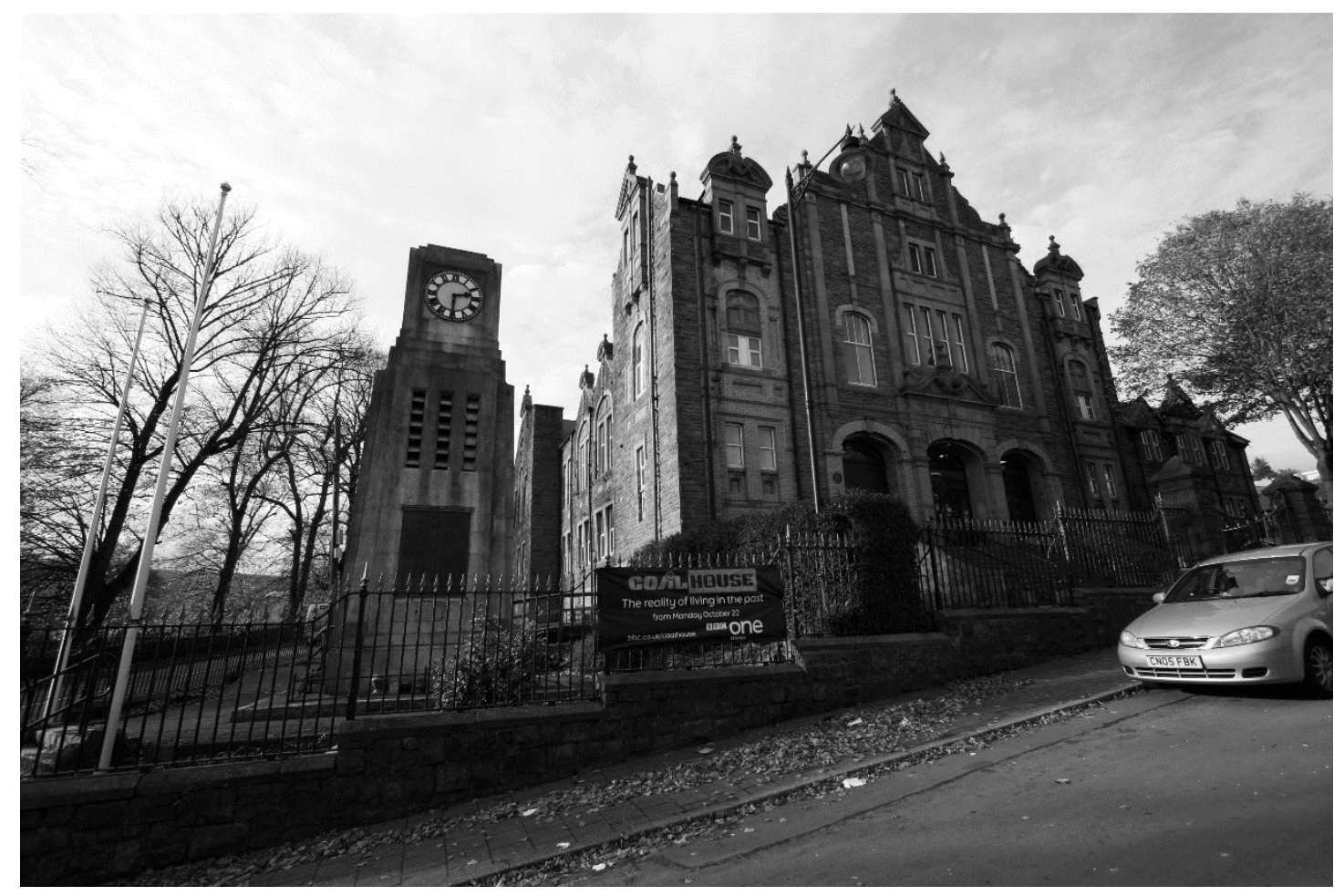

Figure 3. War Memorial and Workingmen's Institute in Blaenavon (Wales, UK). (C) Darren Wyn Rees. 


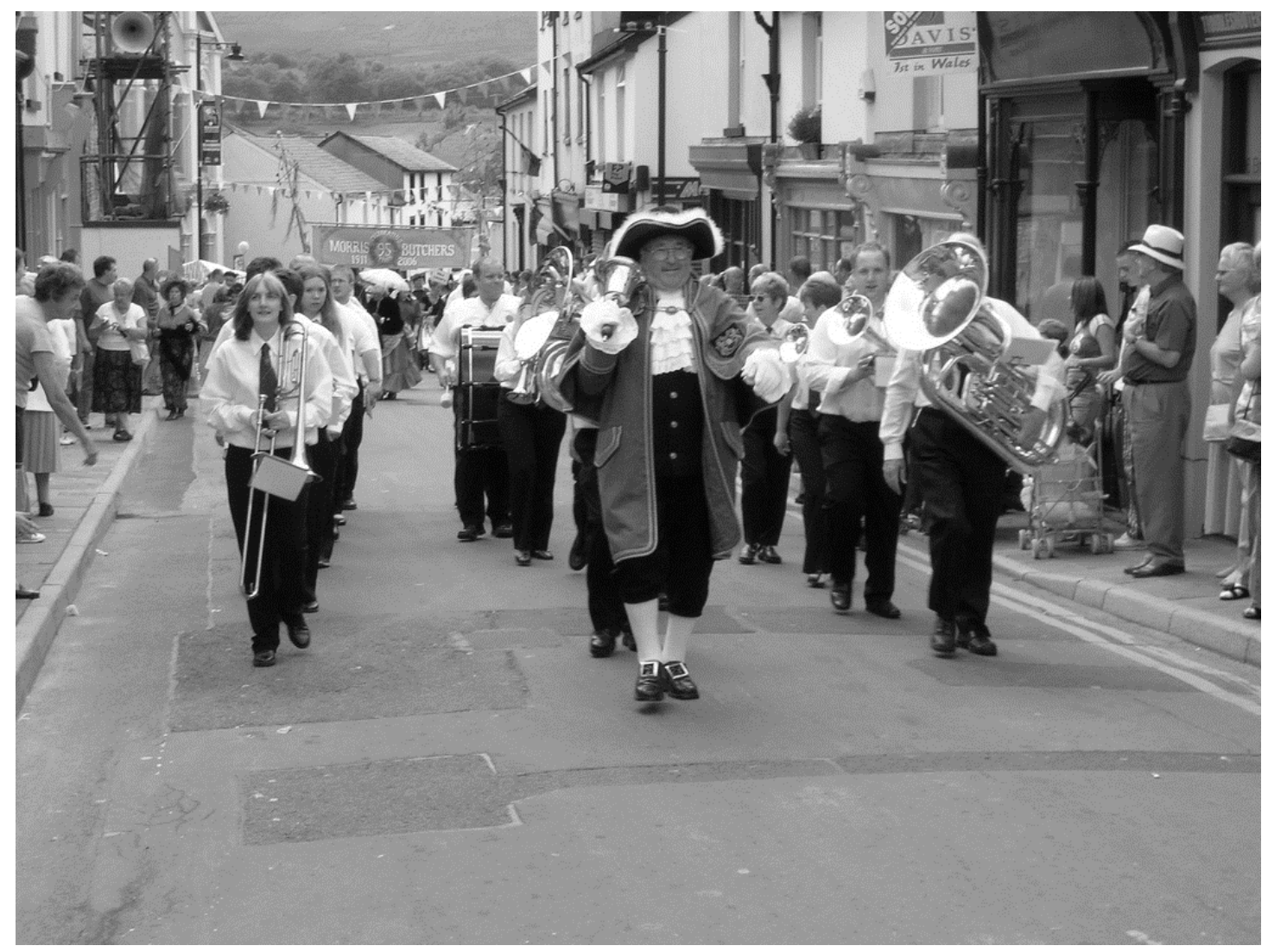

Figure 4. Blaenavon World Heritage Day, 2006. (C) Ric Beachey.

However, most people felt that the town had improved in physical appearance at least, and community pride was also beginning to improve. Many were pleased with the World Heritage listing. In fact, one major community-led event, the annual 'World Heritage Day', which is a rebranding of the annual carnivals held since the early 1960s, attracts around 10,000 visitors yearly (Figure 4). Everyone that spoke about this event referenced it as a source of pride. It is organized and run almost solely by local residents. This suggests that in order to achieve goals like social cohesion or empowerment, local people need to be actively involved in the decision making which affects their lives rather than professionals merely implementing topdown economic regeneration projects.

The Blaenavon Partnership now recognizes the need for more community-led projects and to become responsive to rather than simply aware of the needs of different sections of society. A temporary, three-year scheme named Forgotten 
Landscape (running from summer 2010) may address these problems. Through various projects, this scheme aims to allow for more extensive engagements with diverse groups and individuals and to deliver real social and economic benefits. Just one example is a project that aspires to tackle the environmentally damaging practice of bike scrambling. By working with local youths to construct dedicated bike trails, the heritage professionals hope to offer practical skills and qualifications related to managing aspects of the heritage landscape. Another project aims to help support local producers such as cheese-makers who use the Big Pit mineshaft to mature their cheeses. These projects are responding to the need to continue regenerating the local economy, but also involve local people and use the cultural and natural heritage of the Blaenavon Industrial Landscape in innovative, mutually beneficial and sustainable ways.

\section{Conflict to collaboration}

In itself, the assertion of outstanding universal value does not give rise to conflict amongst members of the local community. Conversely, The World Heritage claim actually produces a sense of pride. However, tension does exist through the approaches to community involvement employed by the heritage professionals. Contemporary social values, like those associated with the Workman's Hall, have yet to be adequately addressed in the heritage-led regeneration process. This is reflected in the way some locals discussed previous heritage projects, which spoke volumes about their perception of being excluded from decisions that have affected their lives.

When heritage is used as part of plans to boost economic and social wellbeing, sustained dialogues between heritage managers and local communities are required, based on reciprocal relationships of trust and honesty. Scholars and professionals working in collaborative archaeological projects have demonstrated that a willingness to be open and honest about one's own views may in fact lead to more interactive and inclusive relationships (McDavid, 2009). Furthermore, we should critically reflect upon our own ideologies and assumptions, confident about our own knowledge and ability to act, but also accepting that our knowledge may be partial or distorted by hegemony (Little, 2007). Projects which demand collaboration should involve a 
ceding of authority by heritage professionals, allowing for professionals and locals to work as equals towards formulating and implementing mutually beneficial projects. The results of truly collaborative projects are generally more ethically and socially relevant, and may be more effectively geared towards problem solving related to issues such as social empowerment and social justice (e.g. Colwell-Chanthaphonh and Ferguson, 2008b).

Heritage professionals may do better by clearly demonstrating that they are working for and with the community rather than (or as well as) for other political or professional stakeholders. In the case of Blaenavon, this latter group would include TCBC and UNESCO. This is particularly important where a community group may not have much time to commit to the meetings or consultations involved in the dayto-day management of a project (McDavid, 2009). I am not implying that heritage managers should have no voice; collaboration is certainly not about handing over all the power to another group, such as a local community. Rather, decisions should be shared and should be reached through an ongoing dialogue, with the recognition that local needs may change over time.

The temporary Forgotten Landscapes scheme will theoretically address the problems encountered in the management of the Blaenavon World Heritage Site to date. The benefits that will hopefully emerge include practical skills and qualifications for local people, and a bolstering of the local economy, but it will hopefully also empower people to become involved in democratic decision-making. Through such schemes the conservation of the World Heritage Site can be linked to the enhancement of local values, empowerment and ultimately wellbeing. For the aims of this temporary scheme to be effective in the long-term, the Blaenavon Partnership should ideally incorporate an interactive collaborative structure into the mainstream management of the industrial landscape-perhaps by establishing a regular community forum. This would allow for local views to resonate. However, without meaningful collaboration with local communities, heritage managers will continue to be addressing perceived needs rather than actual needs. 


\section{References}

Blaenavon Partnership. Nomination of the Blaenavon Industrial Landscape for the Inclusion in the World Heritage List. Cwmbran, Torfaen County Borough Council, 1999. 87 p.

Blaenavon Partnership. 2010. Blaenavon Industrial Landscape World Heritage Site. Management Plan 2010-2015. Draft document available at Blaenavon World Heritage Centre.

Colwell-Chanthaphonh, C.; Ferguson, T. J. Introduction: The collaborative continuum. In: Colwell-Chanthaphonh, C.; Ferguson, T. J. (eds.). Collaboration in Archaeological Practice: Engaging Descendent Communities, p. 1-32. Lanham, AltaMira, 2008a. 300 p.

Colwell-Chanthaphonh, C.; Ferguson, T. J. (eds.). Collaboration in Archaeological Practice: Engaging Descendent Communities. Lanham. AltaMira, 2008b. 300 p.

de Merode, E.; Smeets, R.; Westrik, C. (eds.). Linking Universal and Local Values: Managing a Sustainable Future for World Heritage. Paris, UNESCO, 2004. 200 p.

English Heritage. Understanding Place. Historic Area Assessments: Principles and Practice. Swindon, English Heritage, 2010. 35 p.

Little, B. J. 2007. Archaeology and civic engagement. In: Little, B. J.; Shackel, P. A. (eds.). Archaeology as a Tool of Civic Engagement, p. 1-22. Plymouth, AltaMira, 2007. 286 p.

McDavid, C. The public archaeology of African America: reflections on pragmatic methods and their results. In: Sørensen, M. L. S.; Carman, J. (eds.). Heritage Studies: Methods and Approaches, p. 217-234. London, Routledge, 2009. 340 p.

Smith, L.; Waterton, E. Heritage, Communities and Archaeology. London, Duckworth, 2009. 174 p. 
Summerby-Murray, R. Interpreting deindustrialised landscapes of Atlantic Canada: memory and industrial heritage in Sackville, New Brunswick. The Canadian Geographer, Vol. 46, No. 1, 2002, p. 48-62.

Swidler, N.; Dongoske, K.; Anyon, R.; Downer, A. (eds.). Native Americans and Archaeologists: Stepping Stones to Common Ground. Walnut Creek, AltaMira, 1997. $320 \mathrm{p}$.

Torfaen County Borough Council (TCBC). Torfaen Landscape Strategy. Volume 5. Blaenavon Tourism and Visitor Amenity Landscape Framework. Cwmbran, Torfaen County Borough Council, 1997.

UNESCO. The Nara Document on Authenticity. Paris, UNESCO, 1994a.

UNESCO. Report of the Expert Meeting on the "Global Strategy" and thematic studies for a representative World Heritage List. 1994b. Available at: http://whc.unesco.org/archive/global94.htm (accessed 22 May 2011).

UNESCO. Convention for the Safeguarding of the Intangible Cultural Heritage. Paris, UNESCO, 2003.

Uzzell, D. 1998. Interpreting our heritage: a theoretical interpretation. In: Uzzell, D.; Ballantyne, R. (eds.). Contemporary Issues in Heritage and Environmental Interpretation, p. 11-25. London. The Stationary Office, 1998. 200 p.

\section{Acknowledgements}

I am grateful to the eighteen individuals who allowed me to interview them for this research. Thanks also to the staff at the Blaenavon World Heritage Centre for being so accommodating during my time in Blaenavon. 